\title{
Changing perspectives on the relationship between heritage, landscape and local communities: A lesson from Borobudur
}

Daud A. Tanudirjo, Jurusan Arkeologi, Fakultas Ilmu Budaya, Universitas Gadjah Mada, Yogyakarta

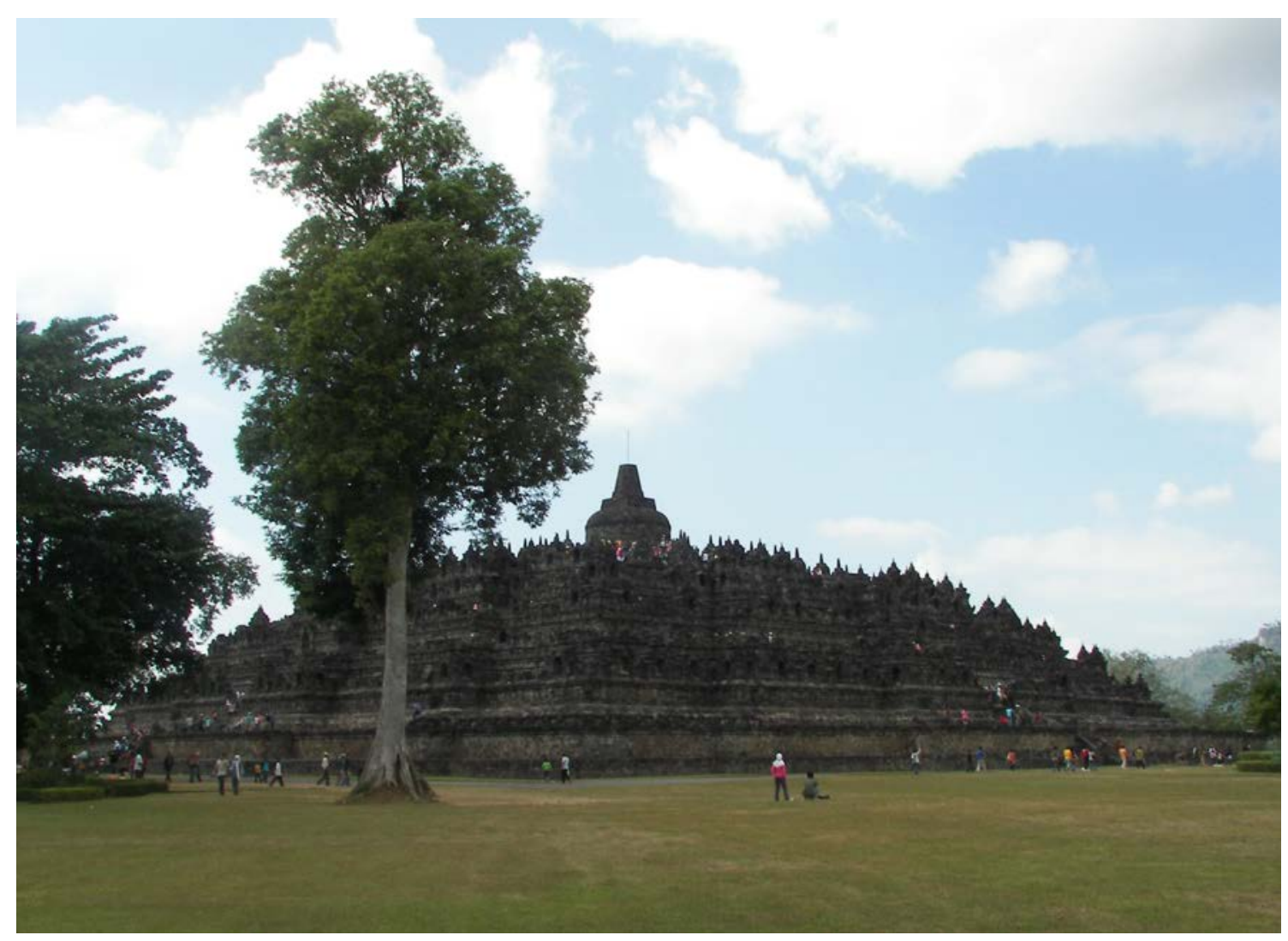

Figure 1. The grandeur of the Borobudur World Heritage site has attracted visitors for its massive stone structure adorned with fabulous reliefs and stupas laid out in the configuration of a Buddhist Mandala.

Source: Daud Tanudirjo.

The grandeur of Borobudur has fascinated almost every visitor who views it. Situated in the heart of the island of Java in Indonesia, this remarkable stone structure is considered to be the most significant Buddhist monument in the Southern Hemisphere (Figure 1). In 1991, Borobudur 
was inscribed on the World Heritage List, together with two other smaller stone temples, Pawon and Mendut. These three stone temples are located over a straight line of about three kilometres on an east-west orientation, and are regarded as belonging to a single temple complex (Figure 2). Known as the Borobudur Temple Compound, this World Heritage Site meets at least three criteria of the Operational Guidelines for the Implementation of the World Heritage Convention: (i) to represent a masterpiece of human creative genius, (ii) to exhibit an important interchange of human values over a span of time or within cultural area of the world, on developments in architecture or technology, monumental arts, town planning or landscape design, and (iii) to be directly or tangibly associated with events or living traditions, with ideas, or with beliefs, with artistic and literacy works of outstanding universal value (see also Matsuura 2005). This is an affirmation of the Borobudur Temple Compound as a magnificent example of the heritage of humankind and a source of pride for Indonesian people, especially the local people of Borobudur who consider themselves direct descendants of the builders.

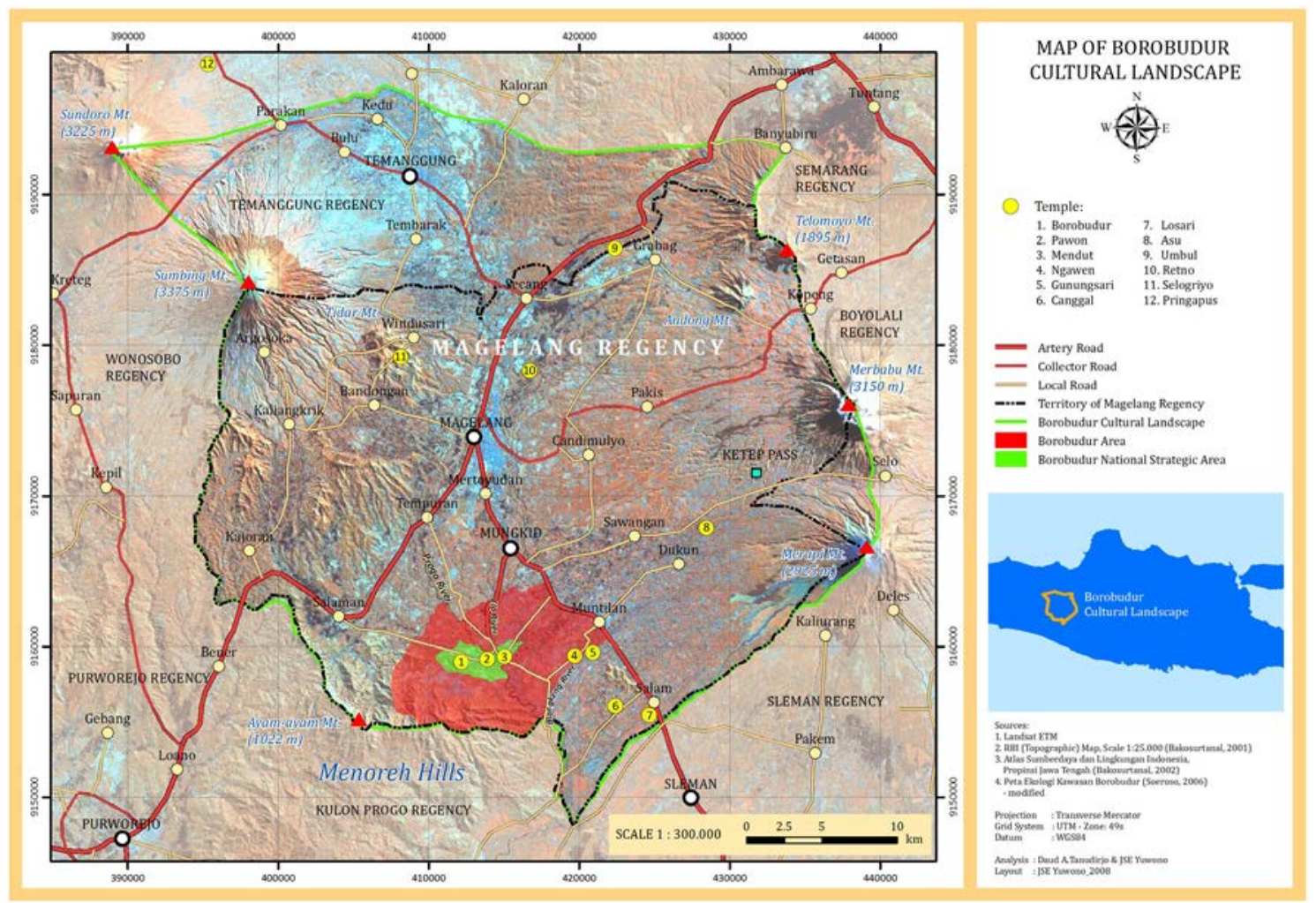

Figure 2. Map showing the Borobudur Temple Compound and the wider cultural landscape. As the local people were excluded from undertaking their traditional practices within the area of the Borobudur monument, they constructed a new wider Borobudur Cultural Landscape which includes the entire area of Kedu Plain encircled by the seven mountains (highlighted).

Source: Prepared by Daud Tanudirjo and J. Susetyo Edi Yuwono.

To maintain and conserve the Borobudur Temple Compound, the Government of Indonesia employs a centralised management policy in which local people are marginalised, having no role in management. This policy has triggered long-standing conflict between the local communities and the Government. The Borobudur case study allows us to evaluate the varied and changing perspectives of local people in relation to the monument Borobudur and the broader cultural landscape. This paper attempts to explicate how these changes occurred and the impact they have had on heritage management in Indonesia. 


\section{A brief history of Borobudur}

Although the Borobudur Temple Compound is comprised of three stone temples - Mendut, Pawon, and Borobudur - it is the latter that is the exclusive focus of interest and most disputed in the Compound's heritage management. Borobudur is the main temple and the largest of the three. The monument was built on a hill that rises about 46 metres above the surrounding plain, with an areal measurement around the base of about 120 metres by 120 metres (Figure 1). More than 55,000 cubic metres of andesite stone was carved to build this massive structure in the form of a low step-pyramid. It consists of six rectangular terraces, three circular terraces, and a huge bell-shaped stupa on top. The wall and balustrade of the rectangular terraces are adorned with meticulously worked reliefs. A series of niches with Buddha statues rise above the lower balustrades and are crowned with small stupas. In total, 432 sitting Buddha statues with various hand-poses (mudras) were placed around the balustrades. On the three circular terraces, perforated larger stupas of 3.8 metres diameter at the base and 3.7 metres in height are arranged in circles containing 32, 24, and 16 stupas from lower to upper terraces respectively. Each stupa contains a sitting Buddha stone statue with dharmacakramudra ("turning the wheel of the law" hand-pose) representing a figure who has attained the highest level of enlightenment, variously known as the Highest Buddha, Vajrasattva (Krom, 1927), or Mahavairocana (Bernet-Kempers 1976).

The dome-shaped structure of Borobudur is commonly described as a replica of the universe and is comprised of four layers: the underworld (kamadhatu), material world (rupadhatu), spiritual world (arupadhatu), and the Eternal world (Nirvana). The first two layers are presented as five square terraces surrounded by walls with more than 1460 panels of relief, while the spiritual and the Eternal layers are symbolised as three round terraces and the main stupa respectively. The reliefs depict at least four themes: the punishment and reward for evil and good conduct (Mahakarmavibhangga), previous lives of the Buddhas or Jatakamala-Avadana, the life of Siddhartha Buddha Gautama or Lalitavistara, and the story of a young man Sudhana in search of the Highest Wisdom or Gandavyuha (Miksic 1990). Following the reliefs consecutively from lower to higher levels, the stories teach us the spiritual path to attain the ultimate Enlightenment. This may also be interpreted as a representation of the essential path of human progression from the physical towards the spiritual (Tanudirjo 2008). The existence of reliefs that could guide viewers on the path to obtain Enlightenment has led many scholars to suggest that Borobudur was built as a place of pilgrimage.

Borobudur can also be viewed as a Mandala, a symbolic diagram consisting of various geometric shapes, such as triangles, squares, and diamonds which are arranged in a circle. Usually a Mandala is used during meditation to help people to obtain better concentration (Walker 1983). In Buddhism, a Mandala is a diagram showing images of gods in specific positions. Each god represents a certain power. The design of Borobudur, especially when seen from above, clearly resembles a Mandala diagram. The placement of Buddha statues with particular hand-poses in specific directions supports this notion (Miksic 1990). However, the unique design of Borobudur has also been interpreted by some scholars as evidence for syncretism between Buddhism and the pre-Hinduistic Javanese beliefs based on ancestor worship. This interpretation is partly based on a phrase in an inscription related to the building of Borobudur, dated to $824 \mathrm{AD}$, which mentions the builder's appreciation of the merit that had been made by his/her predecessors (de Casparis 1950).

Borobudur Temple Compound was constructed during the reign of Syailendra dynasty around the ninth century $\mathrm{AD}$ and took more than 50 years to complete (Dumarcay 1978). Its location was selected in relation to a number of considerations (Voute 2005). Located amidst the bowllike Kedu Plain of Central Java, Borobudur is very close to the geographic centre of Java Island. The area is surrounded by mountains and hills, namely: Merapi, Merbabu, Andong, Tidar, 
Sindoro, Sumbing, and the Menoreh Hills respectively (Figures 2 and 3). This configuration references the location of Mount Mahameru, the centre of the Universe and the abode of the gods. According to Hindu-Buddhist cosmology, this sacred mountain is encircled by concentric rings of sea and land. Recent geological research in the vicinity of Borobudur has discovered evidence of an ancient lake that once existed around Borobudur (Murwanto et al. 2004). The occurrence of an ancient lake surrounding Borobudur was hypothesised by W.O.J. Niewenkamp more than 75 years ago (de Casparis 1981:70, 83). Its verification is indeed a strong indication that Borobudur was constructed to represent Mahameru. What is more, astronomical studies show that Borobudur, Mendut, and Pawon are arranged along an east-west axis pointing directly to the Merapi volcano to the east (Figure 3). The alignment is considered to symbolise the birth of a New World Age (Voute 2005; see also Tanudirjo 2011). On certain days of the year, the sun rises behind the volcano and sheds rays of light on Borobudur before touching the surrounding plain. Such a scene may have been imagined and configured in the construction of Borobodur by its architect as a symbol of Enlightenment. Clearly the Borobudur Temple Compound was designed to reference and illustrate the cultural and spiritual world of the community that constructed it.

The glorious age of Borobudur was not long-lasting. The monuments declined in use shortly after the centre of Old Javanese Kingdom shifted from Central Java to East Java around the end of tenth century AD, possibly due to the continuous eruption of Merapi and other volcanoes around this area. However, Borobudur may not have been totally abandoned. Its existence is noted in Nagarakrtagama, a fourteenth century Old Javanese manuscript. The temples appear to have been totally abandoned around the sixteenth century when the influence of Islam grew stronger in Central Java (Tanudirjo 2011). By the eighteenth to nineteenth century AD, some Javanese manuscripts describe Borobudur as merely a sacred mound, or even as a dangerous place to visit. Most of Java was ruled by the Islamic Kingdom and the majority of its population had been converted to Islam by this time. There was no sign of Buddhism existing in Central Java and Borobudur had been almost forgotten.

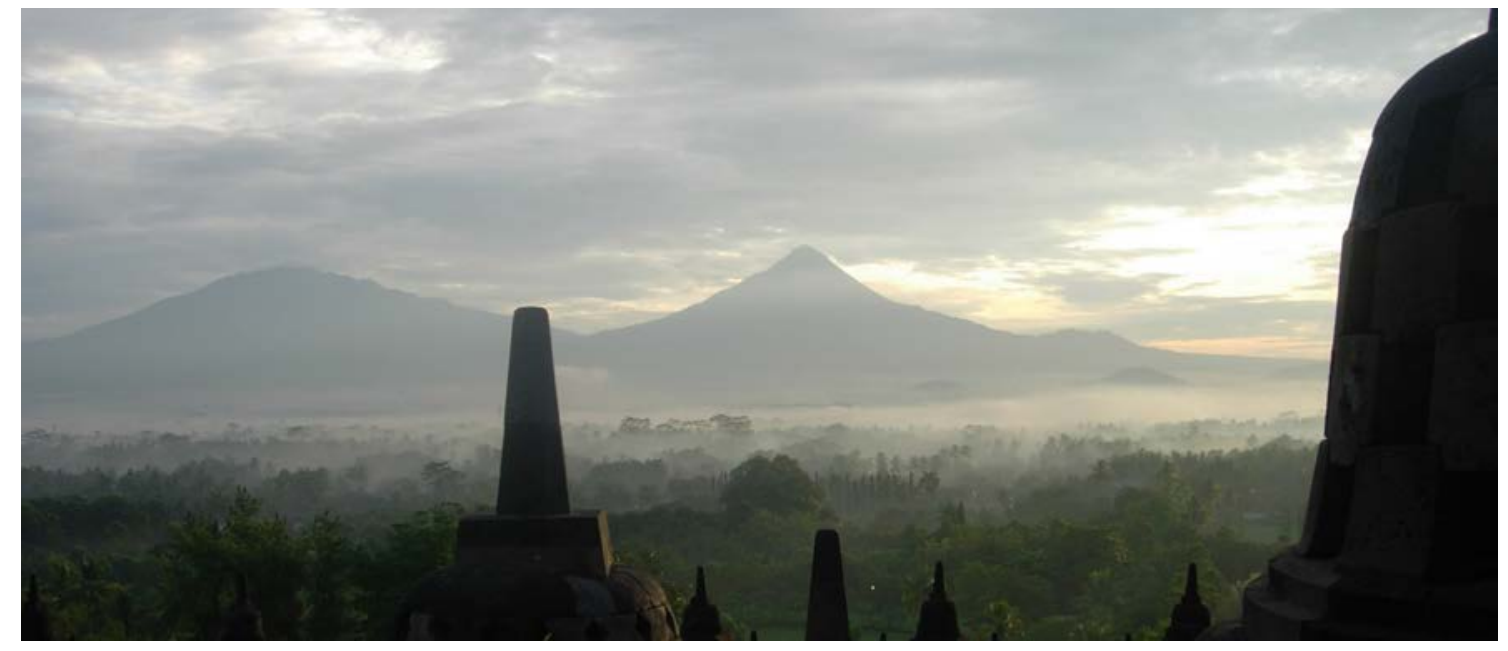

Figure 3. The Borobudur cultural landscape is surrounded by mountains and hills. Merapi and Merbabu volcanoes are among the mountains that mark the boundary to the east.

Source: Daud Tanudirjo.

\section{The rediscovery and restoration of Borobudur}

Borobudur was rediscovered in 1814 when Java was under the authority of Governor General Sir Thomas Stamford Raffles (1811-18). Knowing of the existence of temple ruins in the Borobudur 
area, Raffles sent H.C. Cornelius to examine the region (Soekmono 1976). With the help of around 200 local labourers, Cornelius cleaned away the vegetation and soil covering the ruins and revealed the ancient monument (Raffles 1817). Subsequently, Borobudur was often visited by Europeans for research and documentation, as well as for recreation (Figure 4). After the exposition, the monument's condition gradually deteriorated and this raised concern among scholars. Deformation of the stone structure, especially the stupas and the three round terraces, endangered the monument. In the early 1900s, the Dutch Government appointed a military officer van Erp to lead the restoration of Borobudur. Van Erp decided to focus the restoration on the three round terraces and the stupas as he considered that the square terraces were still in relatively good condition. After four years of hard work, from 1907 to 1911, van Erp managed to restore all the stupas, including the main stupa, and the three upper terraces. This restoration saved Borobudur from collapse, at least temporarily (Tanudirjo et al. 1994).

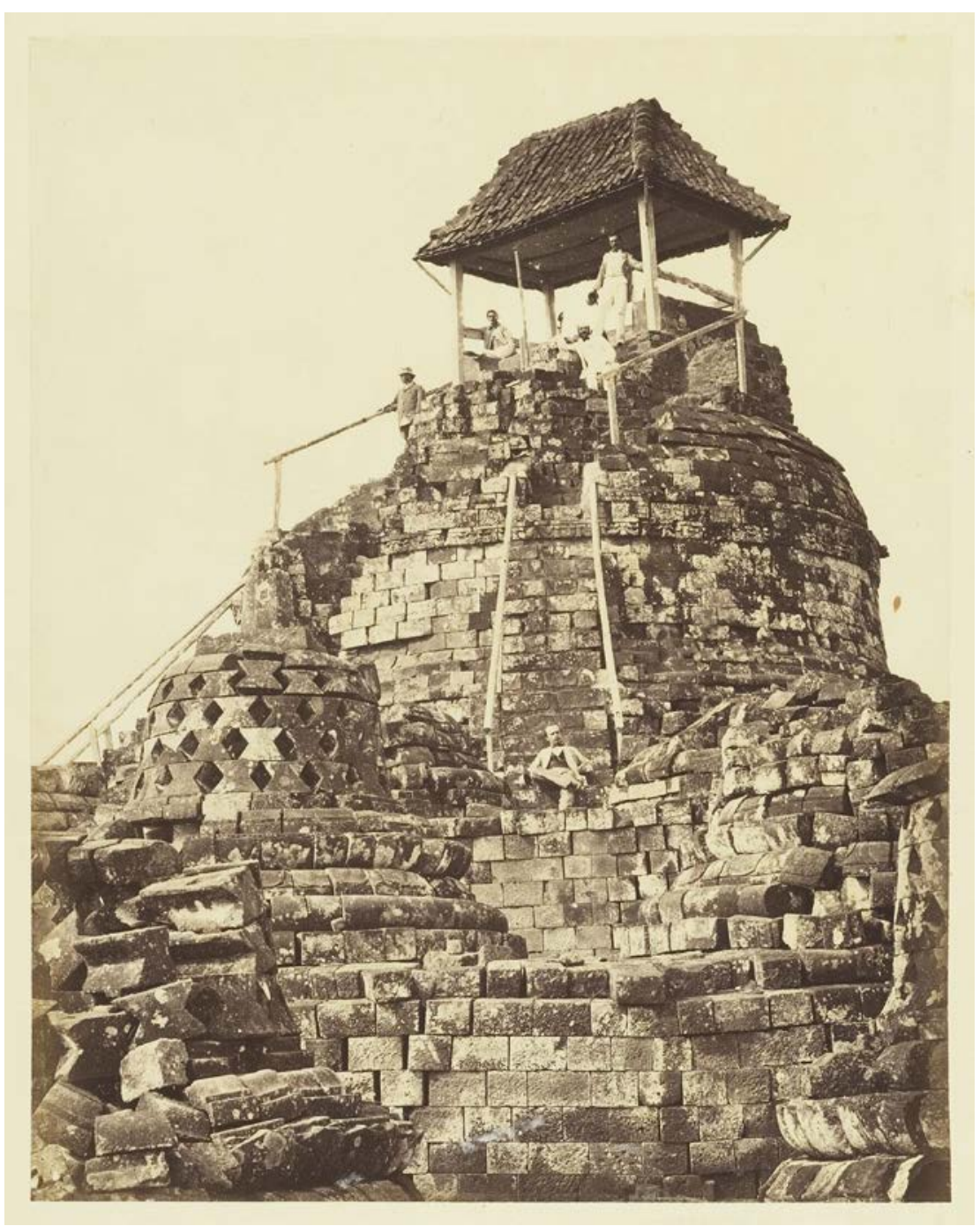

Figure 4. Since it was discovered in 1814 , Borobudur has attracted visitors for recreation as well as research. The Dutch officials built a viewing hut on the top of the Main Stupa.

Source: Courtesy of KITLV/Royal Netherlands Institute of Southeast Asian and Caribbean Studies.

Twenty years after van Erp's restoration, another problem emerged: the square terraces began to deform due to water seepage. No significant action was taken by the Dutch Government to address this. It was not until the 1950s, after the independence of Indonesia, that Borobudur was 
declared an endangered monument. The new Indonesian Government initiated an international campaign to save it but this was unsuccessful. Although lacking sufficient resources, in the 1960s the Government strove to save the monument from ruin. It was not until 1972 when UNESCO agreed to take part in the restoration that real progress was made. With financial support from Japan, West Germany, Britain, Belgium, and Australia, UNESCO began an international safeguarding campaign for the monument. Following this, the Indonesian Government and UNESCO decided to carry out a more comprehensive restoration, executed from 1973 to 1983. Since 1978 the Japan International Cooperation Agency (JICA) has assisted the Indonesian Government to establish a master plan for managing the Borobudur-Mendut-Pawon complex. According to the plan, the Borobudur area should be developed as the Borobudur National Archaeological Park and an integrated zoning system should be implemented. The zonation consists of five zones (JICA Study Team 1979):

Zone I Zone for protection and prevention of destruction of the physical environment of the archaeological monuments

Zone II Zone for provision of park facilities for the convenience of visitors and preservation of historical environment

Zone III Zone for regulation of land use around the parks and preservation of the environment while controlling development in areas surrounding the parks

Zone IV Zone for maintenance of historical scenery and prevention of destruction of the scenery

Zone $\mathrm{V}$ Zone for undertaking archaeological survey over a wide area and prevention of destruction of undiscovered archaeological monuments

At the conception stage of the JICA masterplan, the cultural landscape of Borobudur was considered as important and meriting protection. A leading Indonesian archaeologist, R. Soekmono, who was project manager of the Borobudur restoration (1971-1983), had expressed his concern regarding the potential impact of the tremendous changes to the Borobudur cultural landscape that were occurring as a result of activities attracted by the newly restored monument, especially the increase in visitation due to its prominence as a tourist destination. Even before the restoration officially concluded, he strongly emphasised the need to establish a plan for the protection of the cultural landscape of Borobudur (Soekmono 1983; see also Tanudirjo 2007). Soekmono's concern was partly accommodated in the JICA masterplan. Zone IV was designed to protect the historic scenery and cultural landscape. However, the plan for Zone IV has never been implemented.

Since the rediscovery of Borobudur, the local population living within the surrounding landscape has embraced the monument and expressed pride in residing in its proximity. They made offerings there and performed traditional ceremonies, including wayang (shadow) puppet show. To celebrate Idul Fitri, the end of Muslim fasting season, they gathered at Borobudur to greet their relatives and friends. They also provided food, souvenirs, and services for visitors to the monument. These actions engendered a feeling of ownership among the local people. They perceived Borobudur to be their heritage, although most of them had no historically informed knowledge of its history. It became part of their life and their cultural identity. The local people considered themselves the guardians of the cultural complex.

To establish Zones I and II, a protected area of about 90 hectares had to be freed up from human settlement. At least 381 households inhabiting five villages were resettled. These local people had to give away their land, mosques, kiosks, cemeteries, and gardens to the Government with very minimal compensation that amounted to only about one fifth of the market value at that time. Although the Government promised to provide jobs for these people during the development stage of the park, only small numbers of local people worked on the project. Some of the local 
people resisted giving up their properties, but as commonly happened at that time, the New Order regime in power used oppressive measures to force them to relinquish their homes and lands and move to other villages or the resettlement locations provided for them. Since then they have had no access to the monuments of Borobodur and consequently they feel disenfranchised from their heritage. Meanwhile, the Government founded a state-owned corporate body, PT Taman Wisata Candi Borobudur and Prambanan, to manage the monuments and the surrounding area which then became Borobudur Tourism Park rather than a National Archaeological Park. The name chosen by management reflects the stance of the Indonesian Government that perceives the Borobudur Temple Compound more as economic resource than a cultural and educational resource.

Although the establishment of the Integrated Zoning System by JICA was aimed at protecting the broader Borobudur landscape (JICA 1979), removing the villagers who had lived there for centuries was actually an act of landscape clearance. A landscape is not only composed of its topography and physical elements, it includes the people who live there, their acts, memories, relations, and the histories they have in that place (see Smith 2008; Thomas 2001). From this perspective, the residents of these villages, with their long-standing relationship with Borobudur, are an integral part of the Borobudur landscape. Landscape is always meaningful for people who have long and close relationships to it. It is often seen as part of their identity and involves a strong sense of belonging (Smith 2008). Hence, the eviction of the local people from their villages and land around Borobudur has predictably caused a terrible impact upon them. It is thus understandable that they resisted the Government edict to move to other places.

On 21 January 1985 a high-explosive bomb exploded on the circle terraces of Arupadhatu. At least nine perforated stupas were damaged (Tanudirjo et al. 1994). Local people were made the scapegoats. A number of prominent leaders who had resisted government control of the monument were brought to the military camp, interrogated and even tortured. They were forced into confessions admitting responsibility for the blast. Fortunately, just a couple days afterward, the real bomber was arrested. He was a Muslim fundamentalist who was afraid of Buddhist revivalism and considered the restoration of the Buddhist monument to be a return to paganism. This traumatic incident terrified the local people of Borobudur and increased their suffering. However, even in the face of such oppression many of them maintained the struggle for greater access to the monument and to be involved in the management of their heritage, although they confronted the Government less overtly. After this time, they exercised different strategies to take hold of their rights.

\section{The management of Borobudur Temple Compound}

In 1992, the Central Government issued Presidential Decree Number 1/1992 which assigned different institutions to manage the five zones of the Borobudur area. Zone I is managed by the Conservation Office of Borobudur which focuses on the conservation of the monument. Zone II is under the management of PT Taman Wisata Candi Borobudur and Prambanan, especially for the tourist activities. Zones III, IV, and V are managed by the local Government (Magelang Residency), which administers the whole area. Strangely, the conservation of Mendut and Pawon is conducted by another office, the Conservation Office of Central Java. The reason for this is that these two monuments are situated in Zone III and are under the management of the Magelang local Government, as a part of the Provincial Government of Central Java. Therefore, at least four institutions are assigned to manage the Borobudur Temple Compound.

Its distribution among different institutions has made management more complicated. The lack of coordination between the institutions jeopardises the implementation of the JICA masterplan 
and generates conflict. Every party pursues its own goals without considering the others and they impose different, and often conflicting, values and meaning on the heritage. The one thing all management bodies have in common is that they barely involve local people in their planning or implementation. The Borobudur Conservation Office is most interested in the academic value and conservation of the monument. PT Taman Wisata Candi Borobudur and Prambanan aims to gain maximum profit or financial value. Similarly, the local Government attempts to raise income from their authorised zones and thus often 'forgets' to enforce necessary regulations. Meanwhile, the local people struggle for their right to have more access to obtain cultural as well as economic benefits from the monuments. The latter becomes essential as more and more local people depend for their subsistence on Borobodur's value as a tourism attraction.

Among the four management bodies, PT Taman Wisata Candi Borobudur and Prambanan is the only profit-oriented body. It is a state-owned corporation which was established to gain as much profit as possible from Borobudur, especially through tourism. Sometime its policies and conduct are not in accord with the conservation principles pursued by other bodies. To obtain more profit, Zone II is often used for activities irrelevant to the heritage, such as to house a flying-fox adventure game and merry-go-round. The protection embankment to the south of the monument was modified to enable the performance of a newly choreographed opera narrating the interpretive history of the construction of Borobudur. Housing facilities formerly constructed for the Borobudur Research Centre were converted to an exclusive hotel. While sometimes it was claimed that the local people were given the opportunity to perform their traditional ceremonies and festivals within Zone II, in fact it was groups of people from outside Borobudur who were invited to perform there. Most of the profit obtained by PT Taman Wisata Candi Borobudur and Prambanan is rendered to the Central Government. Only a very small portion is shared with the Borobudur Conservation Office to support conservation programs, and even less is contributed to local community development programs. The Magelang Local Government gains a considerable sum of money from various taxation schemes and parking fees. Obviously, in using this management model, the Indonesian Government was implementing the spirit of the socalled "archaeology in the service of the state" (Kohl and Fawcett 1995: 3) where "archaeology has served the needs of the nation-state and those in a position of power and privilege. Archaeologists often work as technicians of the state, under a system of 'Governmentality'... In actuality, public access to the material and intellectual results of archaeological research remains limited, and in most contexts 'held in the public trust' means 'owned and managed by the state' for particular state interests and purposes" (Nicholas and Hollowell 2006: 60). This is exactly what happened at Borobudur.

With such a management system, it is obvious local people obtain almost no financial or cultural benefits from Borobudur's heritage. An official Government statistic shows that Borobudur is the poorest village in Magelang Residency (Biro Pusat Statistik 2006). As they have no land, gardens, or paddy-fields, the local people have been increasingly forced to rely on tourism related activities for their subsistence. But as most of them do not have any skills base, the simplest way for them to make a living is to become vendors or street hawkers. Everyday more than 3000 hawkers swarm the monuments around Borobudur temple (Figure 5). This has caused problems for the tourists as well as religious pilgrims. Cultural Resource Management (CRM) expert Myra Shackley (2001) commented that Borobudur would no longer be a good place for pilgrimage since "any spiritual experience is militated against by crowds of persistent hawkers". A significant decline in the number of foreign visitors caused tension between local people and PT Taman Wisata Candi Borobudur and Prambanan to be amplified. The latter institution blamed local people, especially vendors and street hawkers, for the decline. For their part, the local people accused the Government of monopolising the management of Borobudur heritage. Local people 
felt betrayed by the Government. They argued that their predecessors had been forced to forfeit their property and heritage and the Government failed to fulfill its promise to improve the quality of life for the local communities of Borobudur. They also complained that PT Taman Wisata Candi Borobudur and Prambanan was allowed to carry out profit-oriented activities in Zone II, which violated the regulations, while local vendors and hawkers were strictly prohibited from entering this zone.

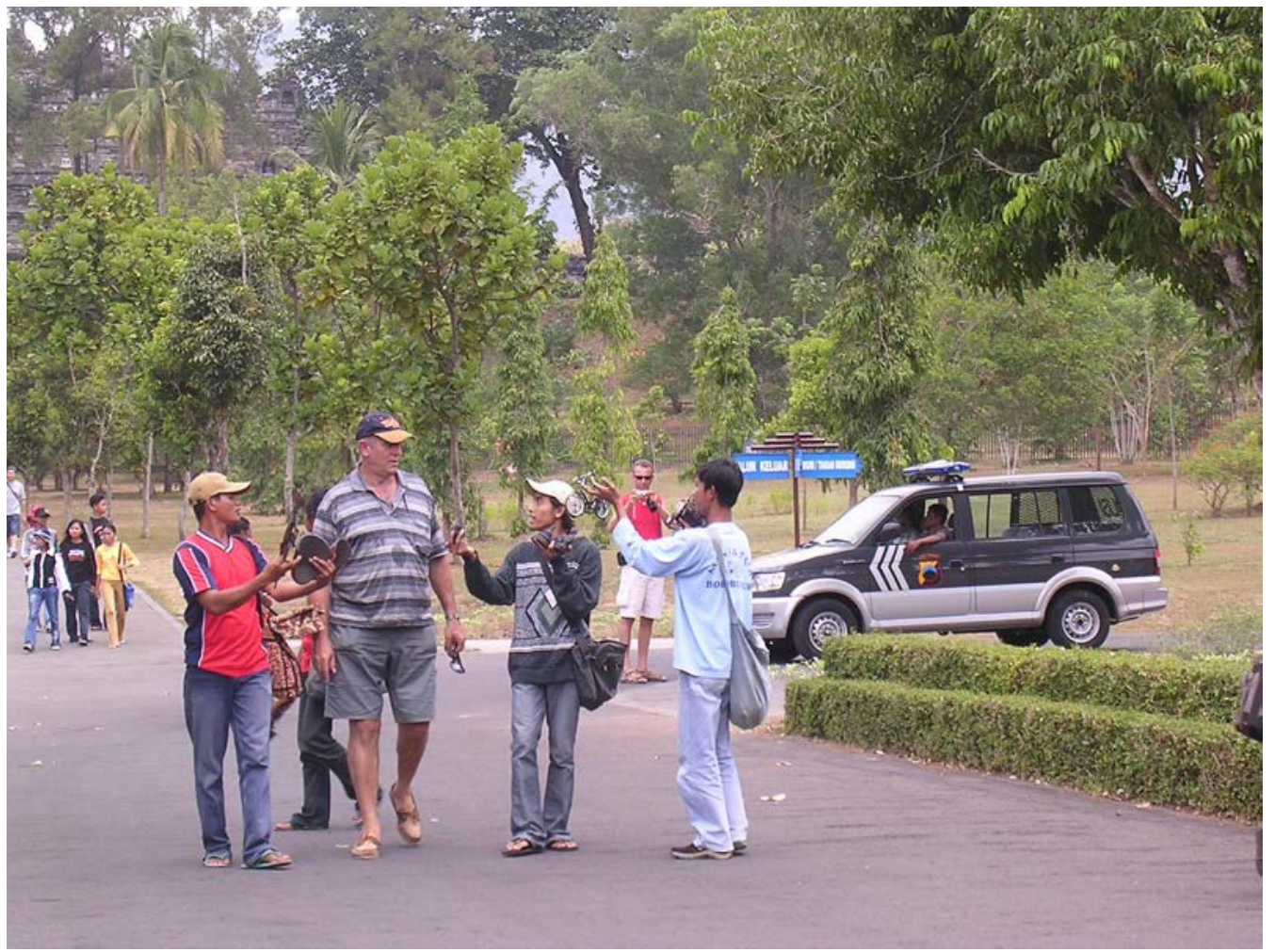

Figure 5. Local people have turned to tourism dependent subsistence since their lands were converted to the Borobudur Tourism Park. Thousands of them have become vendors or street hawkers who often chase visitors to buy their merchandise causing much inconvenience.

Source: Daud Tanudirjo.

Soon after the New Order regime collapsed in 1998, local people felt they had the freedom to access their Borobudur heritage. They acted as if the Government had no control of management anymore and that the extant regulations had been relinquished. They held several public meetings and rallies to protest the Government "ownership" of Borobudur. Vendors and hawkers behaved uncontrollably. They freely entered and offered their merchandise in Zone II, even up to the top of the monuments. PT Taman Wisata Borobudur and Prambanan lacked the courage to stop them as this was an expression of the people's euphoria after more than 30 years under the New Order authoritarian Government. But, this lapse in Government control was only temporary. Through mediation, gradually Government agencies regained their control of Borobudur.

Unable to have greater access to Borobudur, the local people pursued a different strategy. They were aware of their inadequate power to change Government policy on Borobudur so they shifted from a focus on access to the monuments to building greater integrity among the local communities. They revitalised their traditional culture by more intensively performing their traditional ceremonies and art festivals outside the protected area. Through such activities, they engaged communities living outside the resettlement areas, as far as the western slopes of Mount Merapi and Merbabu (Figure 3). It was apparent that the local people impacted by 
the establishment of the Borobudur Tourism Park were not only attempting to reinforce social cohesion among themselves but also to build more intimate relationships with communities outside them. Through this effort they were creating wider social networks and solidarity for their cause. Interestingly, the local people then started to identify themselves not only with Borobudur, but also with the broader landscape surrounding it and even with the Kedu Plain in general. They fostered a new awareness among the wider communities that the Borobudur landscape covers not only the Borobudur-Pawon-Mendut temples and the nearby villages but the entire area encircled by the seven mountains (Merapi, Merbabu, Andong, Tidar, Sindoro, Sumbing and the Menoreh Hills) (Figures 2 and 6) and extended their cultural landscape. This is evident in the transformation from what was initially the Borobudur Folk Festival to the Five Mountains Festival, and then Seven Mountains Festival (Figure 7). And, now even the concept of Borobudur as a Mandala (see above) has been embraced by the younger generation of Borobudur.

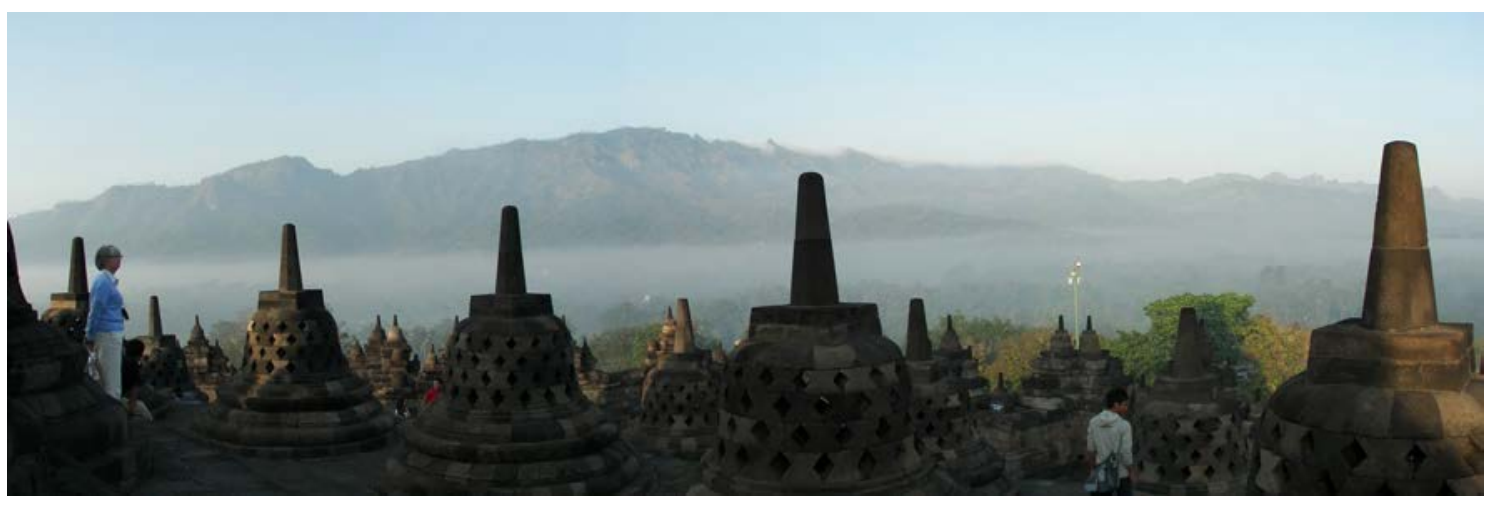

Figure 6. Menoreh Hills. The undulating Menoreh Hills have become the boundary of the Borobudur cultural landscape to the south.

Source: Daud Tanudirjo.

It cannot be denied that the construction of a new, wider Borobudur landscape was partly influenced by the academics who carry out research, teach field schools, and encourage community empowerment in the Borobudur area. Most of them work closely with and build good relationships with the local people. It was through the academics that the notion of the original Borobudur cultural landscape was introduced. In fact, most prominent leaders within the local community who actively engaged in the construction of the new Borobudur cultural landscape were generally closely associated with the academics. It was from academics that the local people learned about the Mandala concept, the cosmology of interrelations between the Borobudur monuments and the surrounding mountains and hills, the existence of an extinct lake around Borobudur, and even a basic knowledge of Cultural Resource Management (CRM). What they learned from the academics played a vital role in triggering their understanding of the wider cultural landscape. It also created a kind of new outward looking mind-set in which they framed their activities.

The ways in which the people of Borobudur attempted to construct a new and wider landscape were various. Sucoro, one of the prominent local leaders who was expelled from his land and even tortured by the military for his resistance, strives to revitalise traditional ceremonies that had almost died out in villages around Borobudur. He has travelled from village to village, some of them in isolated remote parts of the Menoreh Hills, to encourage the inhabitants to maintain their traditional ceremonies, arts, crafts and other cultural events (Figures 6 and 7). Once every two or three months, he gathers a considerable number of people from different villages around Borobudur to conduct the so-called Pitutur meeting in which some of the attendants sing traditional songs offering good advice (Pitutur literally means 'a good say'). Inspired by field 
schools held by academics at Borobudur, he started to organise his own style of field school for local people, especially the younger generation, in which they study many subjects, from practical skills (such as how to make certain kinds of craft items and videos) to more conceptual ones (such as CRM, social participation and heritage conservation). He often invites scholars to share their knowledge with local participants at the events he organises (Sucoro pers. comm., 2006).



Figure 7. As the local people had no access to Borobudur anymore, their traditional art festivals were annually conducted outside the protected zone to keep their social solidarity and integrity intact. Traditional cultural events played an important role in constructing the wider Borobudur Cultural Landscape.

Source: Photo courtesy Waring Info Jagad Cleguk.

A progressive young leader, Jack Priyatna, took a different approach. With some of his colleagues he initiated a tourism organisation network. Although he sometimes guided tourists visiting Borobudur, his focus is actually to develop tourism outside the protected areas as a means to empower not only local people who live close to Borobudur but also in the surrounding areas. As one of a younger generation who is fully aware of the injustice of the Government's treatment of his people, he is sceptical that the present management system of Borobudur will enhance the welfare of local people. He assumed that his people would not be able to rely on their heritage claims to the Borobudur monuments for their livelihoods. Therefore, he turned his attention to exploring other aspects of the broader heritage of the Borobudur region, such as the traditional villages with their own unique cultural as well as natural assets. He designated several villages each with a special attraction, such as a good view towards Borobudur, or traditional manufacture of pottery, vermicelli, tofu, or arts and crafts, and around these he created a Borobudur ecotourism package. Tourists travel around the Borobudur area by traditional horse-cart and visit villages with specialties. Along the road, they can view Borobudur from different aspects (Figure 8), appreciate an alternative experience and "visit and enjoy the real and comprehensive Borobudur heritage". The tourism organisation network also initiated geological tourism around Borobudur to see the traces of Borobudur's ancient lake (Jack Priyatna pers. comm., 2009) (Figure 9). 


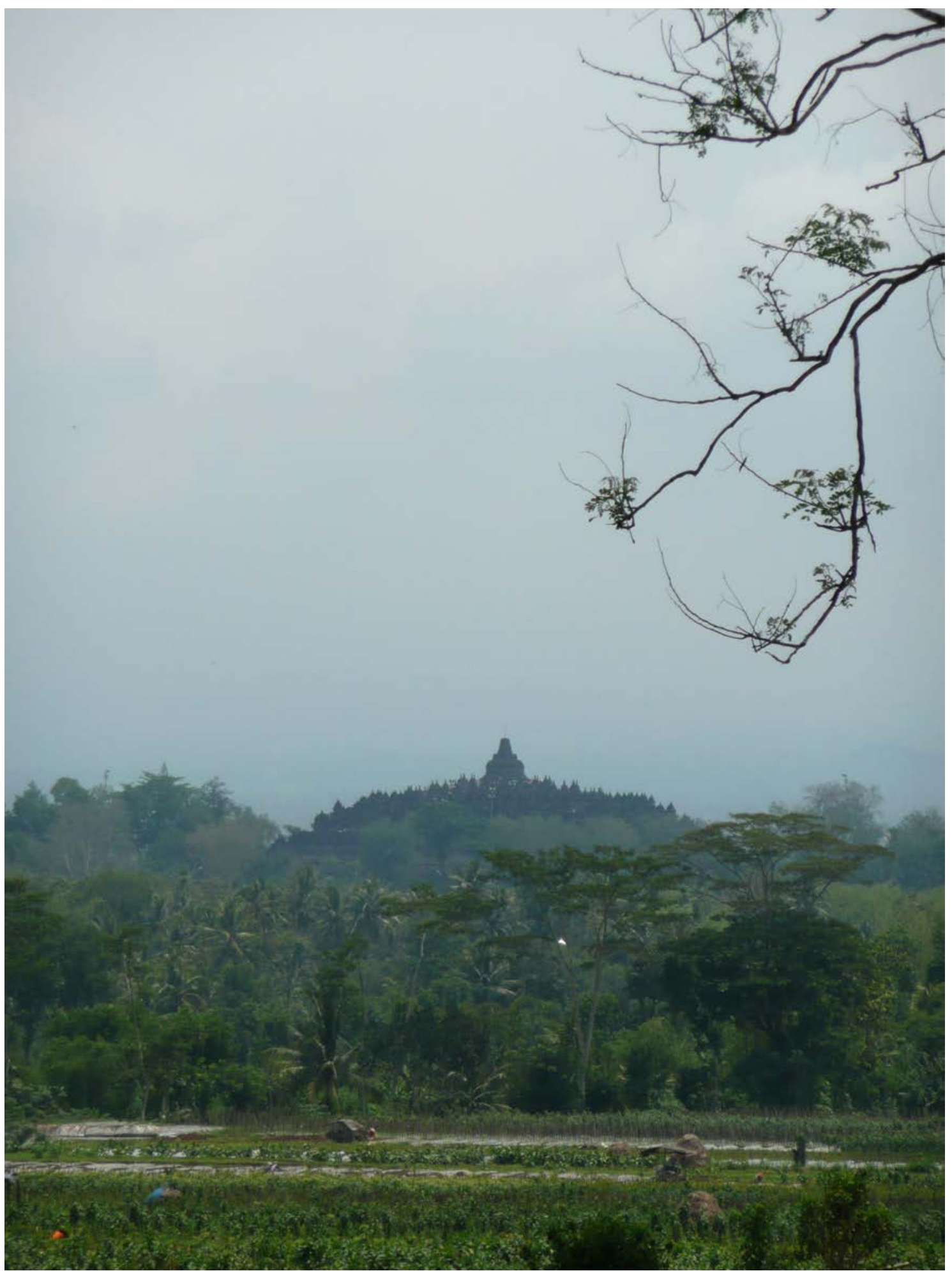

Figure 8. In response to their limited access to Borobudur, young people in local communities have taken the initiative to organise alternative tours which introduce visitors to the wider area around Borobudur, takes them to villages and provides views of the monuments from outside the protected area. This initiative was part of their effort to create a wider cultural landscape for Borobudur.

Source: Daud Tanudirjo. 


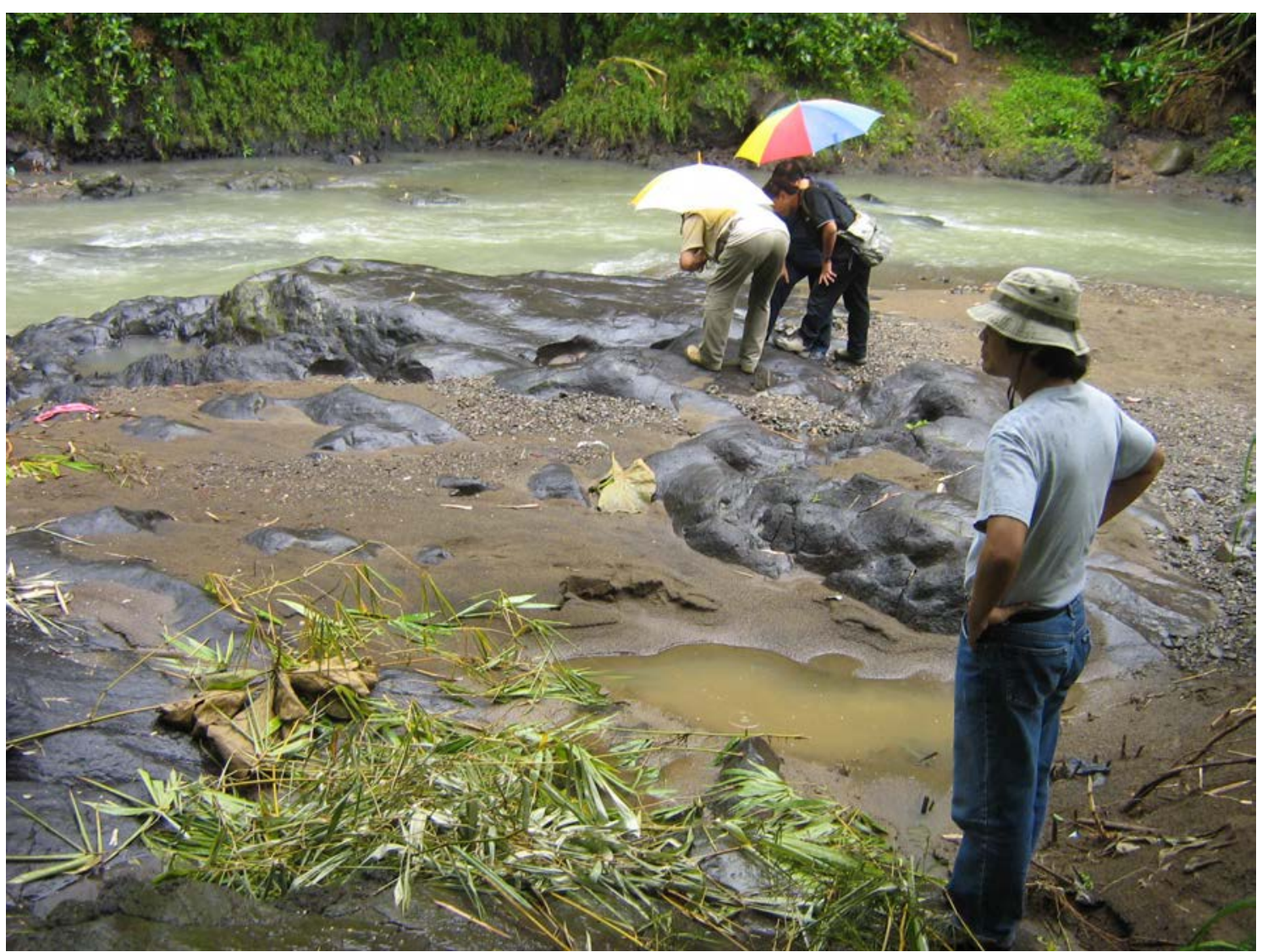

Figure 9. Evidence of the existence of an ancient lake around Borobudur has been incorporated into alternative tours organised by the young local people of Borobudur.

Source: Daud Tanudirjo.

Futhermore, Priyatna promoted the Mandala concept for the management of Borobudur. It means that the Borobudur monument can be seen as the centre of the Mandala which attracts a great energy that can then be distributed to surrounding areas so that they in turn have the energy to protect Borobudur. The basic principle is that the management of Borobudur should not be focused on the ancient monuments alone, but also on the villages in the broader landscape. Hence, the more than two millions visitors who come every year to Borobudur would not solely spend their time in the Tourism Park, but would be encouraged to visit the rural areas around Borobudur. This strategy encourages PT Taman Wisata Candi Borobudur and Prambanan to work hand in hand with the local people and not monopolise the Borobudur Temple Compound. Such an approach has the benefit of reducing the burden on the monuments caused by large numbers of visitors, at the same time as dispersing prosperity to surrounding areas. Priyatna believes this Mandala concept will build up synergy among the stakeholders of Borobudur, between central and local Governments, between local people and the management authorities of Borobudur, and even between visitors and local people. All the stakeholders have their own position and power within a particular area, but they share responsibility and rights to make the system balanced. This is how the Mandala concept works.

Sucoro's and Priyatna's initiatives are indeed only a few examples of many other efforts by the local people of Borobudur in response to Government control of the existing management. All the initiatives made by the local people have played a crucial role in changing perspectives on relations between local people, heritage, and the landscape. They mean that Borobudur heritage is not only contained in the ancient monuments, but intertwines with all natural, demographic, 
and cultural aspects that exist within the wider area of Borobudur. And this eventually leads to the construction of a wider Borobudur cultural landscape that includes almost the entire Kedu Plain encircled by the seven mountains and hills. This changing perspective generates greater solidarity and stronger ties among the local people that significantly increases their bargaining power with the Government. Hence, the Borobudur cultural landscape has become a negotiating arena for a range of stakeholders.

The pressure brought to bear on the Central Government has ultimately encouraged it to change its policy on the management of the Borobudur Temple Compound. Of course, such pressure came not solely from the local people but also from academics, as well as UNESCO via the World Heritage Centre. Since the 1990s, academics have expressed their concern about Government management of Borobudur Temple Compound that focused almost exclusively on the built monuments and created inequality and conflict among the stakeholders. Since 2000, more academics have become part of the worldwide paradigm change in cultural resource management (see Tanudirjo 2006) that gives a greater role to local communities in the management of their heritage. This paradigm promotes the view that heritage should not be viewed as static and pertaining only to the past, but rather to be an integral part of the wider landscape, including the people who live around it and/or own the heritage (Shackley 2001; Smith 2004). The emergence of this new concept of cultural landscapes (Taylor 2003) also influenced Indonesian academics working in heritage management and has become one of the significant aspects of the Indonesian Charter for Heritage Conservation declared by heritage management activists and academics in 2003. With this new perspective, academics have tried to convince Government of the necessity to manage Borobudur Temple Compound as a cultural landscape in which local people and their traditional life style are integral, and to consult and involve local communities in planning processes and execution of CRM.

Lack of community participation in the management of Borobudur Temple Compound has become UNESCO's concern as well. This was partly brought about by escalating conflict due to the Government's intention to build the so-called Pasar Seni Jagad Jawa (The Spirit World of Java Art Mall) in Zone III of Borobudur in 2002. This project aimed to solve the problems caused by the large numbers of vendors and street hawkers at Borobudur. According to this plan, they would be concentrated in one big market and not allowed to sell their merchandise outside. However, this was not done in consultation with local communities and it instigated nationwide protest. In April the following year, UNESCO-ICOMOS carried out Reactive Monitoring, followed by the Fourth International Experts Meeting at Borobudur organised by the Indonesian Government and UNESCO in July. On both occasions, the aspirations of the local people were collected and discussed. As a result, UNESCO recommended that the Government set up a conservation and management policy that would benefit local people. The policy should not only focus on the Borobudur temples but should embrace the wider cultural context of the monuments (Engelhardt et al. 2003; Adhisakti 2003).

The Indonesian Government anticipated these pressures by promoting a new catch phrase "the second stage of Borobudur restoration". In essence, over the next 20 years, this concept aims to restore within communities the socio-cultural relationships that are jeopardised by the current management system. In 2004, the Minister of Culture and Tourism appointed steering and organising committees to operationalise the concept. Most of the members were Government officials. Unfortunately, when another Reactive Monitoring was carried out by UNESCOICOMOS in 2006, it was found that the committees had achieved nothing. The report noted that an Action Plan drafted by the commitees to improve community roles in the management of Borobudur World Heritage was apparently only formulated as objectives, and there was no clear indication of responsibility to implement the plan. Hence, it was stressed again in the 
recommendation the need to strengthen the management system by establishment of a single management authority which includes representatives of local and Central Governments as well as local communities. The new management authority would ensure the protection of the monuments and their wider setting and the provision of benefits to the local communities (Boccardi et al. 2006).

The pressure brought to bear by local communities, academics, and the international bodies has prompted the Government to reconsider seriously the management policy of the Borobudur area. More and more high-level officials now realise the policy to exclude local people and focus only on the monuments is counter-productive. There is growing awareness that the significance of Borobudur World Heritage lies not only with the monuments but also with their natural setting or landscape, as well as with the communities living within the Borobudur area. In the last three years this changing perspective has been recognised through the review process of Presidential Decree no. 1/1992 that identified the source of conflict. In 2011, a draft of an integrated management plan for the Borobudur Temple Compound and surrounding areas was submitted to the Minister of Culture and Tourism. It is now being considered at the InterMinisterial Forum. Furthermore, this new perspective is being considered in the management plans of other World Heritage sites in Indonesia.

\section{Epilogue}

From Borobudur, we learn that the relationships between local people, heritage and landscape has changed over the course of time. Interestingly, this relates closely to the way its heritage has been managed. When Borobudur was still buried by earth and vegetation, it was considered a dangerous sacred place that was part of an unknown and different world. As the splendour of the monuments were revealed by the efforts of H.C. Cornelius in 1814, the local people started to identify themselves with them. They positioned themselves as the descendants of the great monument builders. Borobudur then became a source of pride and the local people were eager to be the guardians of this heritage. Through their various activities, such as village parades, art festivals, Idul Fitri celebrations and traditional ceremonies conducted around the monuments, the local people tried to always to renew and strengthen their traditional ties with Borobudur.

Under colonial Government administration at that time, the local people still had relatively open access to their heritage. However, since the 1970s the traditional ties between the local people and the monuments were disrupted by the Indonesian Government's policy of management, which began ironically as a desire to safeguard them. To facilitate extensive restoration, further protection and preservation of Borobudur-Pawon-Mendut complex, the Indonesian Government resettled local people who had lived nearby the monuments for hundreds of years. These local communities were then denied access to their heritage. Having lost their lands, their traditional cultural ties with the monuments gradually became economic ones as they now relied on tourism for subsistence. On the Indonesian Government side, the perspective shifted from academic to economic interests when they replaced the Borobudur National Archaeological Parks with the Borobudur Tourism Park. This is also evident in the Government establishment of a profitoriented state corporation, PT Taman Wisata Candi Borobudur and Prambanan, to manage the heritage.

The desire of the local people to reclaim a relationship with their heritage led to the creation of the Borobudur cultural landscape. They identified themselves as part of a wider society that included communities living in the area encircled by the seven mountains, as well as with the ancient communities who built the monuments, thereby uniting the past and the present. These new relationships seem to have engendered stronger solidarity and ties among them. 
By embracing the broader landscape and its population, they gain broader alliances and more power to negotiate with the Government, which is now seriously reconsidering the management policy of Borobudur World Heritage. A new policy is being prepared which will accommodate greater involvement of local people and comprehensive conservation of the wider Borobudur cultural landscape.

The Borobudur case study encapsulates a situation that is quite common in countries with a colonial history, one where the post-colonial Government claims a sole right to manage 'its' heritage. Similarly, this will tend to happen in countries with an "archaeology in the service of the state" perspective (Kohl and Fawcett 1995: 3). In these situations, the Government acknowledges no relationship between heritage and the living cultural traditions of local people. Consequently, it also disregards the landscape as a contextual setting for heritage that also requires management, as its focus is solely on the built environment. It is this perspective that allowed the Government to justify its decision to expel the local population from Borobodur in order to control the heritage. Consequently, heritage becomes isolated from its socio-cultural environment. It becomes an island in the past, static and disconnected from living tradition and practice, where the interpretation of meaning is imposed by the authority that manages it and is biased by that perspective. It is clear then that the establishment of a protected area by means of eviction and disenfranchisement of local people is not an effective measure for protecting heritage. Potentially, it will trigger long-lasting conflict among the stakeholders, which is counter-productive to the aims of heritage management.

\section{References}

Adhisakti, L.T. 2003. Community Participation and Future Development of Borobudur Temple and its Environment. A paper presented in the Fourth International Experts Meeting on Borobudur in Borobudur 4-8 July 2003.

Bernet-Kempers, A.J. 1976. Ageless Borobudur. Wassenaar, Servire.

Biro Pusat Statistik. 2006. Kabupaten Magelang dalam Angka 2006. Magelang: Bappeda - Biro Pusat Statistik Kabupaten Magelang.

Boccardi, G., Brooks, G. and Gurung, H. 2006. Mission Report: Reactive Monitoring Mission to the Borobudur Temple Compounds, World Heritage Property, Indonesia 18-25 February 2006.

de Casparis, J.G. 1950. Prasasti Indonesia I. Bandung: A.C. Nix.

de Casparis, J.G. 1981. The dual nature of Barabudur. In: Gómez, L.O and Woodward, H.W. (eds), Barabudur: History and Significance of a Buddhist Monument, pp. 47-83. Berkeley: Asian Humanities Press.

Dumarcay, J. 1978. Borobudur. Kuala Lumpur, Oxford University Press.

Engelhardt, R., G. Brooks, and Schorlfemer, A. 2003. Mission Report: The Borobudur Temple Compound, Central Java, Indonesia UNESCO-ICOMOS Reactive Monitoring Mission, 16-20 April 2003.

JICA Study Team. 1979. Borobudur - Prambanan National Archaeological Parks. Japan International Cooperation Agency.

Kohl. P.L. and Fawcett, C. 1995. Archaeology in the Service of the State. In: Kohl, P.L. and Fawcett, C. Nationalism, politics, and the practice of archaeology, pp. 3-18, London: Cambridge University Press.

Krom, N.J. 1927. Barabudur: Archaeological Description. The Hague: Martinus Nijhoff. 2 volumes.

Matsuura, K. 2005. Foreword. In: Anom, I.G.N. (ed.), The Restoration of Borobudur, p. 9. Paris: UNESCO. 
Miksic, J.N. 1990. Borobudur: Golden Tales of the Buddhas. Periplus.

Murwanto, H., Gunnell, Y., Suharsono, S., Sutikno S., and Lavigne, F. 2004. The Borobudur monument (Java, Indonesia) stood by a natural lake: chronostratigraphic evidence and historical implications. The Holocene, 14 (3): 459-463.

Nicholas, G. and Hollowell, J. 2006. Ethical Challenges to a Postcolonial Archaeology: the Legacy of Scientific Colonialism. In: Hamilakis, Y. and Duke, P. (eds.), Archaeology and Capitalism: From Ethics to Politics, pp. 59-82, California, Left Coast Press.

Raffles, T.S. 1817. The History of Java. Oxford: Oxford University Press. 1978 edition.

Shackley, M. 2001. Managing Sacred Sites: Service Provision and Visitor Experience. London: Thomson Learning.

Smith, A. 2008. Landscapes of Clearance: Archaeological and Anthropological Perspectives. In: Smith, A. and Gazin-Schwartz, A. (eds). Landscapes of Clearance: Archaeological and Anthropological Perspectives, pp. 13-45, California, Left Coast Press.

Smith, L. 2004. Archaeological Theory and the Politics of Culture Heritage. London, Routledge.

Soekmono, R. 1976. Chandi Borobudur: A Monument of Mankind. Amsterdam: Van Gorcum.

Soekmono, R. 1983. Usaha Demi Usaha Menyelamatkan Candi Borobudur, in Menyingkap Tabir Misteri Borobudur. Prambanan: PT Taman Wisata Candi Borobudur dan Prambanan, pp. 16-17. (Originally published in daily newspaper Sinar Harapan on 17 February1983).

Tanudirjo, D.A. 2006. Heritage for All, Changing Perspective on Heritage Management in Indonesia. A paper presented in the Rethinking Conference on Cultural Resource Management in Southeast Asia, National University Singapore, 25-27 July 2006.

Tanudirjo, D.A. 2007. Cultural Landscape Heritage Management in Indonesia: an Archaeological Perspective. A paper presented in the First International Symposium on Borobudur Cultural Landscape Heritage. Centre for Heritage Conservation Universitas Gadjah Mada, 20 April 2007.

Tanudirjo, D.A. 2008. Inspirational Borobudur. A paper presented in a Cultural Dialogue "Borobudur dalam Jalinan Religi, Seni, dan Sejarah”. Jogja Gallery, 6 May 2007.

Tanudirjo, D.A. 2011. Dampak Erupsi Gunung Merapi Terhadap Candi Borobudur. In: Sutopo, M. (ed.), Menyelamatkan Candi Borobudur dari Erupsi Merapi. Magelang, Balai Konservasi Peninggalan Borobudur.

Tanudirjo, D.A., Prasodjo, T., Yuwono, J.S.E. and Nugrahani, D.S. 1994. Kualitas Penyajian Warisan Budaya kepada Masyarakat, Studi Kasus Manajemen Sumberdaya Budaya Candi Borobudur. Research Report. Yogyakarta: Pusat Antar Universitas Studi Sosial, Universitas Gadjah Mada.

Taylor, K. 2003. Cultural Landscape as Open Air Museum: Borobudur World Heritage Site and its Setting. Humanities Research Vol. 10 No. 2, 2003, pp. 51-62.

Thomas, J. 2001. Archaeologies of Place and Landscape. In: I. Hodder (ed.), Archaeological Theory Today, pp. 165-186. Cambridge, Polity.

Voute, C. 2005. A New Perspective on Some Old Questions Pertaining to Borobudur. In: Anom, I.G.N. (ed.), The Restoration of Borobudur, pp. 213-249. Paris, UNESCO.

Walker, B. 1983. Hindu World, an Encyclopedic Survey of Hinduism. Vol. II. Munshiram Manoharlal Pusblisher.

World Heritage Center UNESCO. 2005. Operational Guidelines for the Implementation of the World Heritage Convention. 